\title{
ANALYSIS OF THE MAGNETIZING INDUCTANCE INFLUENCE ON CURRENT STRESSES OF THE WIDE-ZVS-RANGE ASYMMETRICAL HALF- BRIDGE CONVERTER
}

\author{
Carlos Henrique Illa Font, Eloi Agostini Junior \\ Federal University of Technology - Paraná, UTFPR, Campus Ponta Grossa \\ Department of Electronics Engineering, DAELE, Ponta Grossa, PR, Brazil \\ Email: illafont@utfpr.edu.br, eloiagostini@utfpr.edu.br
}

\begin{abstract}
This paper presents the analysis of the magnetizing inductance influence on the current stresses of the asymmetrical half-bridge (ASHB) DC-DC converter power stage components. One solution for extending the soft-switching operating range is to reduce the magnetizing inductance, which has the collateral effect of increasing the converter's conduction losses. Hence, in order to meet trade-off requirements of high efficiency at light load with minimum heavy load conduction loss penalty, the impact of magnetizing inductance value on the ASHB converter current stresses is quantified. A $500 \mathrm{~W}, 300 \mathrm{~V}$ input, $60 \mathrm{~V}$ output, $50 \mathrm{kHz}$ laboratory prototype is built to verify the ZVS-range operation and efficiency penalty for several values of magnetizing inductance.
\end{abstract}

Keywords - Asymmetrical Half-Bridge DC-DC Converter, Magnetizing Inductance, Wide-ZVS-Range, Zero-Voltage-Switching.

\section{INTRODUCTION}

Isolated ZVS (zero-voltage-switching) DC-DC converters are used in several applications where strong requirements should be met, such as: simple and compact power circuit, easy controlling, safe and reliable operation especially for the power active switches, high efficiency and low cost.

In battery charger applications, for portable electronics equipments or electrical/hybrid vehicles, ZVS in a wide load range is important since the converter might be operating at no-load condition for a long period of time. When the battery is charged, the output current is absolutely zero and the converter should be able to safely operate under the zero load condition [1]-[3].

Fuel cell energy systems in distributed generation for standalone and grid-connected applications also requires wide power variation. The high frequency transformer isolated DC-DC converter translates the low fuel cell stack voltage to higher than the peak of the utility line or inverter output voltage specification with necessary isolation. Soft switching is necessary to operate the converter at high frequency and to achieve small size, light weight, and lowcost converter [4].

In telecommunication power systems with distributed power system concept, the operation of isolated ZVS DC-DC converter over wide load range can be essential for the overall high-efficiency system composed of three parts:

Manuscript received 20/10/2014. First revision 05/02/2015. Accepted for publication 05/02/2015, by recommendation of the Regular Section Editor Cassiano Rech. power factor correction converter, front-end DC-DC converter and point-of-load converter [5], [6].

In applications where the output power demand varies over a wide range, most ZVS DC-DC converter topologies are not able to maintain soft-switching for low output current values, implying an efficiency reduction at light load conditions. Aiming to address this issue, several solutions have been proposed for the extension of ZVS range in isolated DC-DC converters [7]-[15]. In [7], [8], a wide ZVS range is performed by means of the utilization of commutation auxiliary circuits (CACs). The CACs are realized with only passive components or the combination of passive components and active switches. In all cases, it increases component count and cost. The solutions presented in [9]-[12] use a dual half-bridge DC-DC converter or two parallel half-bridge DC-DC converters. These approaches are a quite complex and double the active switch count. The advantage is the zero circulating current.

Regarding to three-level DC-DC converters, in [14] a passive CAC approach is used for extending ZVS range and an active CAC is proposed in [15].

In [12] the authors comment on the approach of reducing the magnetizing inductance of the transformer to achieve a wide ZVS range. However, the mathematical analysis is not performed in order to quantify its impact on conduction losses. Thus, it is not completely evident that this approach is in fact inadequate for achieving wide ZVS range in the asymmetrical half-bridge (ASHB) DC-DC converter.

The commutation analysis of the ASHB converter that relies on the magnetizing inductance adjustment for extending the ZVS range is presented in [13]. It is an interesting solution when the equipment cost is crucial, since there is no need for additional components in the circuit. The major drawback of this solution is the increase of conduction losses due to higher current stresses experienced when the magnetizing inductance value is reduced. In order to quantify this behavior, the analysis of magnetizing inductance influence on current stresses of the wide-ZVS-range asymmetrical half-bridge converter is carried out in this paper.

First, the static analysis is presented in Section II. Section III presents the ASHB components current stresses. The experimental results are shown in Section IV. Finally, the conclusions are stated in Section V.

\section{STATIC ANALYSIS}

Figure 1 shows the ASHB converter topology. In the conventional ASHB converter analysis [16], the effect of magnetizing inductance $\mathrm{L}_{\mathrm{m}}$ in the energy transfer process is 
neglected due to its reduced influence. For the proposed converter operation, where $\mathrm{L}_{\mathrm{m}}$ value is reduced in order to extend the soft-switching operation range, ignoring the magnetizing current would certainly lead to inaccurate equations for predicting voltages and currents in the circuit. Thus, $\mathrm{L}_{\mathrm{m}}$ influence on energy transfer process has to be computed if an adequate converter design is desired. Moreover, this detailed analysis is fundamental for computing the current stresses on the ASHB converter elements.

All equations that provide values of currents in the ASHB converter elements, which are derived in the following analysis, are given on their normalized form. This normalization is used to achieve a generic representation of the ASHB static behavior, and is performed according to:

$$
\bar{I}_{x}=\frac{4 f_{s} L_{d} I_{x}}{V_{i n}}
$$

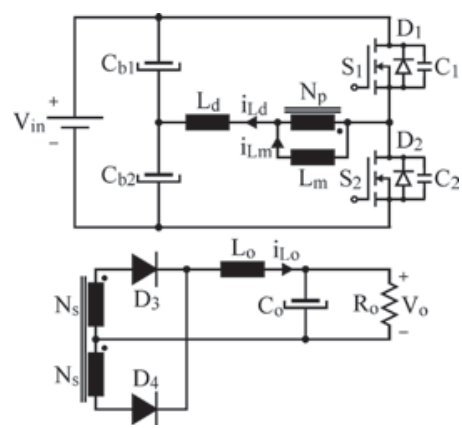

Fig. 1. Asymmetrical half-bridge DC-DC converter.
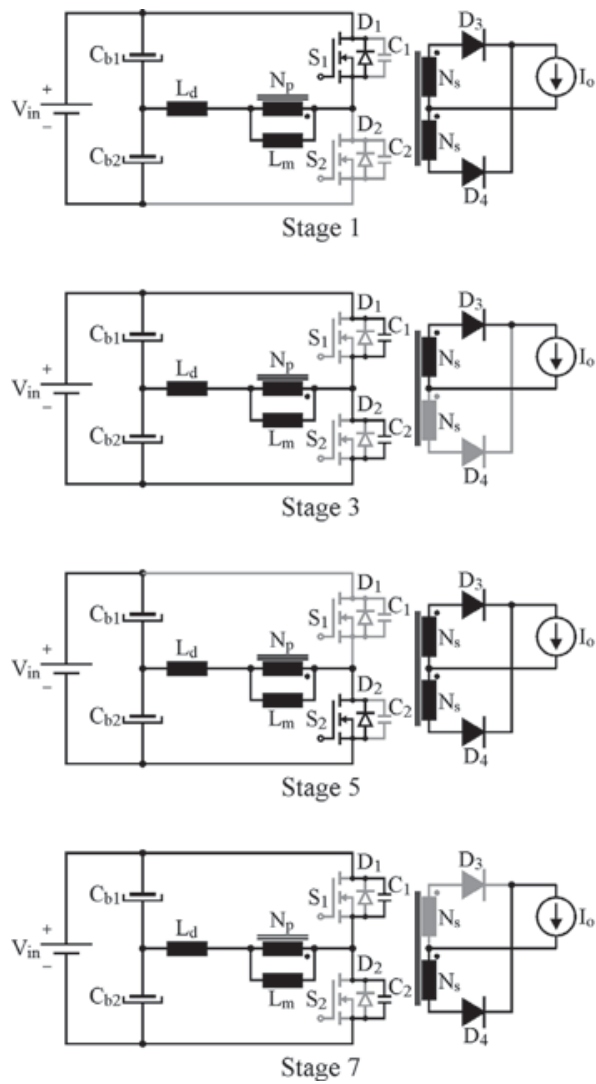

Fig. 2. ASHB converter operation stages. where:

$-\bar{I}_{x}$ : normalized current in a circuit element "x";

- $I_{x}$ : current in a circuit element "x";

- $L_{d}$ : leakage inductance;

- $f_{s}$ : switching frequency;

- $V_{\text {in }}$ : input voltage.

Equation (1) demonstrates how electric current in any circuit element " $\mathrm{x}$ " is normalized, and is often used within this paper for exposing the analyses results. Currents through elements placed on the secondary side of the transformer are further divided by the transformer's turns ratio $\left(\mathrm{N}_{\mathrm{p}} / \mathrm{N}_{\mathrm{s}}\right)$ when normalized, in order to be referred to the primary side of the transformer.

\section{A. Operation Stages and Waveforms}

Figure 2 presents the eight operation stages that occur within one switching cycle considering that the energy stored in $\mathrm{L}_{\mathrm{d}}$ is enough to guarantee complete voltage transition from $V_{\text {in }}$ to zero across both $S_{1}$ and $S_{2}$. The eight operating stages are described as follows:

- Stage $1\left(t_{0}-t_{1}\right)$ : At $t=t_{0}$, diode $D_{1}$ becomes forward biased and both $\mathrm{D}_{3}$ and $\mathrm{D}_{4}$ are also conducting, implying that there is no energy transferred to the output. This stage ends when $i_{L d}$ assumes the value of $I_{0}{ }^{\prime}+I_{L m 2}$.

- Stage $2\left(\mathbf{t}_{\mathbf{1}}-\mathbf{t}_{\mathbf{2}}\right)$ : As $\mathrm{i}_{\mathrm{Ld}}$ reaches the value of $\mathrm{I}_{\mathrm{o}}{ }^{\prime}+\mathrm{I}_{\mathrm{Lm} 2}$ diode $\mathrm{D}_{4}$ cuts off and energy begins to be transferred from the input to the output. This stage persists until the switch $S_{1}$ is turned-off.
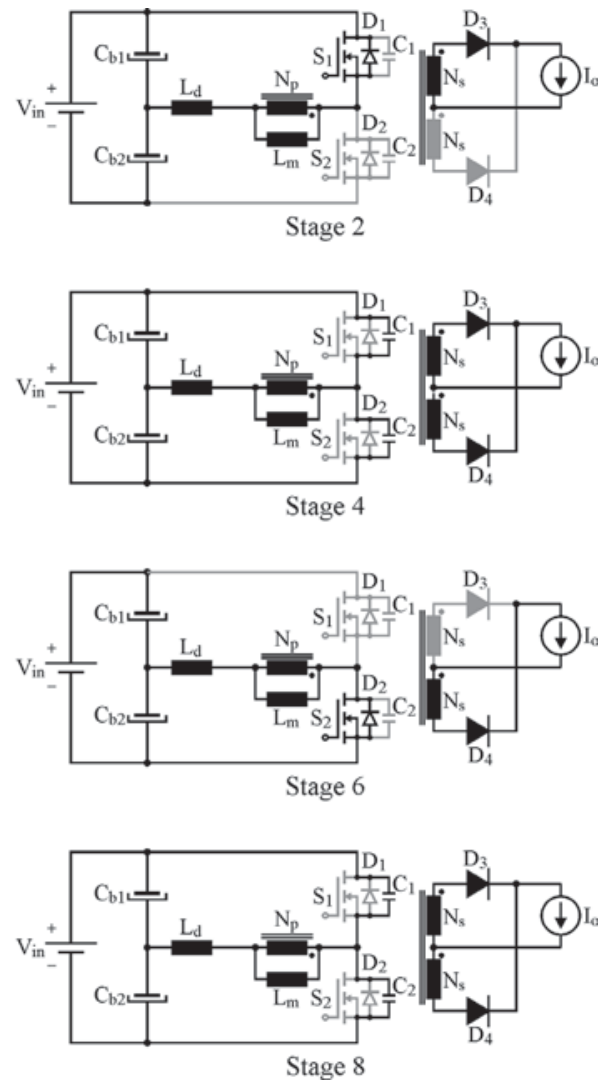
- Stage $3\left(\mathbf{t}_{\mathbf{2}}-\mathbf{t}_{\mathbf{3}}\right)$ : After $\mathrm{S}_{1}$ is blocked, current $\mathrm{i}_{\mathrm{Ld}}$ starts charging and discharging $\mathrm{C}_{1}$ and $\mathrm{C}_{2}$, respectively. At $\mathrm{t}=\mathrm{t}_{3}$, diode $\mathrm{D}_{4}$ starts conducting since voltage $\mathrm{v}_{\mathrm{C} 1}$ reaches the value of (1-D). $V_{\text {in }}$ and the Stage 3 ends.

- Stage $4\left(\mathbf{t}_{\mathbf{3}}-\mathbf{t}_{\mathbf{4}}\right)$ : Stage 4 begins when the respective values of voltages $v_{C 1}$ and $v_{C 2}$ are (1-D). $V_{\text {in }}$ and $D . V_{\text {in }}$. During this stage, $\mathrm{L}_{\mathrm{d}}, \mathrm{C}_{1}$ and $\mathrm{C}_{2}$ form a resonant circuit and, if there is enough energy stored in $\mathrm{L}_{\mathrm{d}}, \mathrm{v}_{\mathrm{C} 1}$ is able to reach the value of $V_{\text {in }}$ and Stage 4 is finished.

- Stage $5\left(t_{4}-t_{5}\right)$ : At $t=t_{4}$, diode $D_{2}$ becomes forward biased, as well as diodes $\mathrm{D}_{3}$ and $\mathrm{D}_{4}$. Therefore, there is no energy being transferred to the output. This stage ends when current through $\mathrm{L}_{\mathrm{d}}$ assumes the value of $-\mathrm{I}_{\mathrm{o}}$ ' $+\mathrm{I}_{\mathrm{Lm} 2}$.

- Stage $6\left(\mathbf{t}_{\mathbf{5}}-\mathbf{t}_{\mathbf{6}}\right)$ : Since $\mathrm{i}_{\mathrm{Ld}}$ reached the value of $-\mathrm{I}_{\mathrm{o}}{ }{ }+\mathrm{I}_{\mathrm{Lm} 2}$, diode $\mathrm{D}_{3}$ cuts off and energy begins to be transferred from the input to the output. Stage 6 ends when $S_{2}$ is turned off.

- Stage $7\left(\mathbf{t}_{\mathbf{6}}-\mathbf{t}_{\mathbf{7}}\right)$ : After $S_{2}$ is blocked, current $i_{L d}$ flows through $\mathrm{C}_{1}$ and $\mathrm{C}_{2}$, charging and discharging these capacitances, respectively. At $t=t_{7}, v_{C 1}$ reaches the value of (1-D). $V_{\text {in }}$ and Stage 7 ends.

- Stage $8\left(\mathbf{t}_{7}-\mathbf{t}_{\mathbf{8}}\right)$ : At $\mathrm{t}=\mathrm{t}_{7}$, voltages $\mathrm{v}_{\mathrm{C} 1}$ and $\mathrm{v}_{\mathrm{C} 2}$ values are (1-D). $V_{\text {in }}$ and D. $V_{\text {in }}$, respectively. As in Stage $4, L_{d}, C_{1}$ and $\mathrm{C}_{2}$ form a resonant circuit. If there is enough energy stored in $\mathrm{L}_{\mathrm{d}}$, voltage $\mathrm{v}_{\mathrm{C} 2}$ is able to reach the value of $\mathrm{V}_{\text {in }}$ and this stage ends.

It is important to observe that the current through $\mathrm{S}_{1}$ may be positive and/or negative during stages 1 and 2, depending on the ASHB converter loading conditions. The same applies to $S_{2}$ during stages 5 and 6 .

The main ASHB converter waveforms are presented in Figure 3.

\section{B. Output Characteristic}

Initially, the static gain $q$ and inductance factor $\alpha$ are defined, respectively, as:

$$
\begin{gathered}
q \triangleq \frac{n V_{o}}{V_{i n}} \\
\alpha \triangleq \frac{L_{d}}{L_{d}+L_{m}}
\end{gathered}
$$

where $n$ is the transformer's turns ratio $\left(\mathrm{N}_{\mathrm{p}} / \mathrm{N}_{\mathrm{s}}\right)$ and $\mathrm{V}_{\mathrm{o}}$ is the output voltage.

In order to determine the ASHB converter output characteristic two simplifications are considered, which are: current ripple through $\mathrm{L}_{\mathrm{o}}$ is neglected and commutation stages 3, 4, 7 and 8 are considered to have a very short duration when compared to the switching period. Therefore, only stages 1, 2, 5 and 6 affect the energy transfer process and the output inductor $\mathrm{L}_{\mathrm{o}}$ behaves as a current source.

By analyzing the equivalent circuit of each operation stage and computing for the average value of $\mathrm{v}_{\mathrm{o}}$, it is possible to demonstrate that:

$$
\frac{n V_{o}}{V_{\text {in }}}=\left(\frac{L_{m}}{L_{d}+L_{m}}\right)\left[(2 D-1)-\frac{4 f_{s} L_{d} I_{o}}{n V_{i n}}\right]
$$

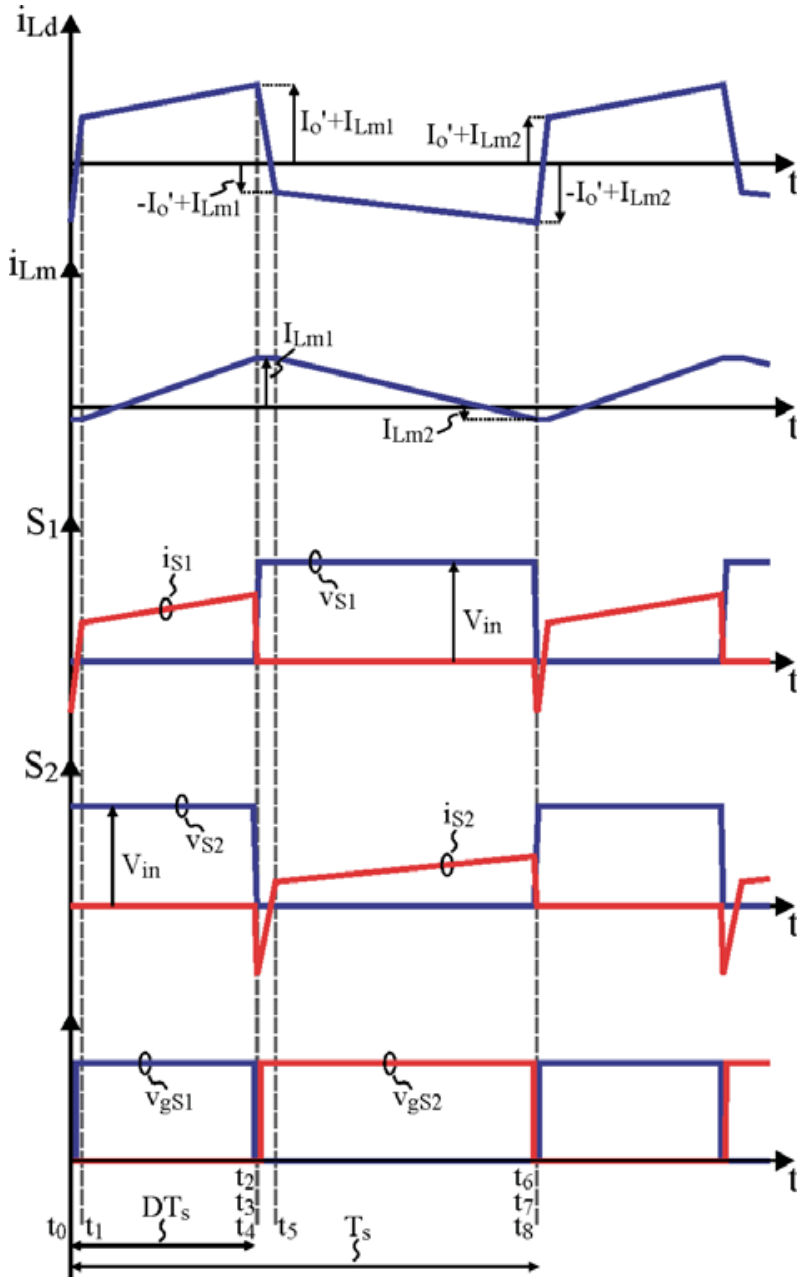

Fig. 3. Main ASHB converter waveforms.

where $D$ is the duty cycle and $I_{o}$ is the output current.

Using (2), (3) and the normalized output current referred to the primary side of the transformer, it is possible to rewrite (4), so that:

$$
\frac{q}{(1-\alpha)}=(2 D-1)-\bar{I}_{o}^{\prime}
$$

Equation (5) provides the ASHB converter output characteristic considering the influence of $\mathrm{L}_{m}$ in the energy transfer process. It is important to observe that as $\mathrm{L}_{\mathrm{m}}$ value decreases the static gain is also decreased. Figure 4 presents some curves generated from (5), which provide the converter's static gain as function of its output current for several values of duty cycle.

\section{Average Magnetizing Current Value}

One important characteristic of the ASHB converter is that the average magnetizing current value is not equal to zero due to the use of asymmetrical PWM. It implies that a DC magnetic flux component appears in the transformer's core, which has to be taken into account to ensure that this element does not operate under saturation conditions. 


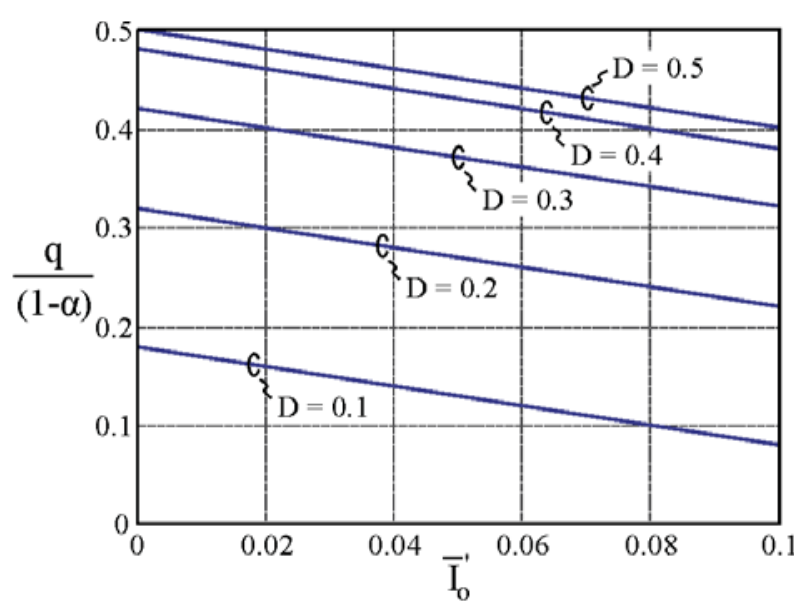

Fig. 4. ASHB converter output characteristic.

From the converter analysis it is possible to compute the parameterized values of $\mathrm{I}_{\mathrm{Lm}, 1}$ and $\mathrm{I}_{\mathrm{Lm}, 2}$, given respectively by:

$$
\begin{aligned}
& \bar{I}_{L m, 1}=(1-\alpha) \frac{\left|\sqrt{1-2\left[\frac{q}{(1-\alpha)}+\bar{I}_{o}^{\prime}\right]}\right|}{q+(1-\alpha) \bar{I}_{o}^{\prime}} q \bar{I}_{o}^{\prime}+\frac{\alpha}{(1-\alpha)} q \\
& \bar{I}_{L m, 2}=(1-\alpha) \frac{\left.\mid \sqrt{1-2\left[\frac{q}{(1-\alpha)}+\bar{I}_{o}^{\prime}\right.}\right] \mid}{q+(1-\alpha) \bar{I}_{o}^{\prime}} q \bar{I}_{o}^{\prime}-\frac{\alpha}{(1-\alpha)} q
\end{aligned}
$$

By solving the integral that provides the average magnetizing current value yields:

$$
\bar{I}_{L m, a v g}=\frac{\left.\mid \sqrt{1-2\left[\frac{q}{(1-\alpha)}+\bar{I}_{o}^{\prime}\right.}\right] \mid}{q+(1-\alpha) \bar{I}_{o}^{\prime}} q \bar{I}_{o}^{\prime}
$$

The graph generated from (8) is shown in Figure 5. This result has to be carefully interpreted, since it could lead to the conclusion that increasing $\alpha$ could be an interesting approach for reducing the average magnetizing current value. The reduction of this average value as $\alpha$ is increased is due to the fact that the duty cycle is adjusted toward the value 0.5 , in order to compensate the loss of static gain originated from the use of higher values of $\alpha$. The characteristic that the magnetizing current average value is reduced as duty cycle value becomes close to 0.5 is another result from the converter analysis.

\section{ASHB COMPONENTS CURRENT STRESSES}

By performing the ASHB converter analysis it is possible to observe that the parameter $\alpha$ has an important influence on the RMS values of the currents through the components of the circuit. Quantifying this influence is important since it gives the basis for an adequate design that relies on the adjustment of the magnetizing inductance for extending the ZVS operation range with minimal impairment to conduction losses. Since the resulting equations of the current stresses analysis are too long, they are not provided in the paper for the sake of brevity. However, the graphs generated using these results are shown in several figures.

From the ASHB converter waveforms one can write the integrals that compute $\mathrm{I}_{\mathrm{S} 1 \text {,rms }}$ and $\mathrm{I}_{\mathrm{S} 2 \text {,rms }}$ values, and the graphs generated using these results are shown in Figures 6 and 7 on their normalized forms.

These results show that both switches $S_{1}$ and $S_{2}$ suffer from higher current stresses as $\alpha$ value is increased. Another important observation is that the switch that remains turnedon during the shorter time $\left(S_{2}\right.$ in this case) has a higher current sensitiveness to the increase of parameter $\alpha$.

By computing the integral that gives the RMS value of current $i_{L d}$, it is possible to generate the graph shown in Figure 8.

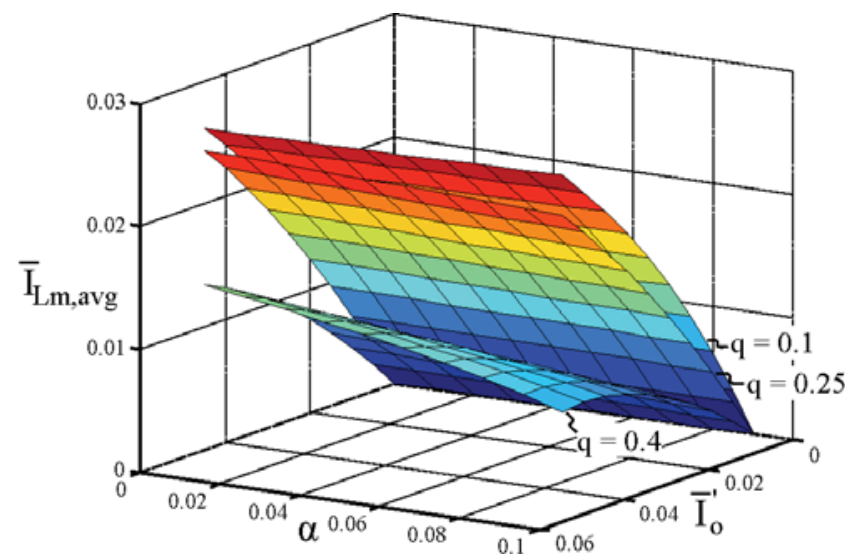

Fig. 5. Normalized average value of magnetizing current.

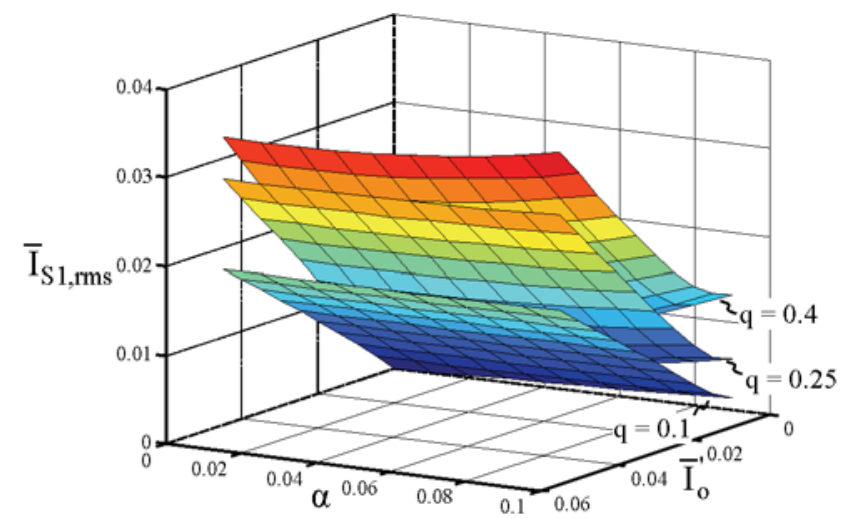

Fig. 6. Normalized RMS value of switch $\mathrm{S}_{1}$ current.

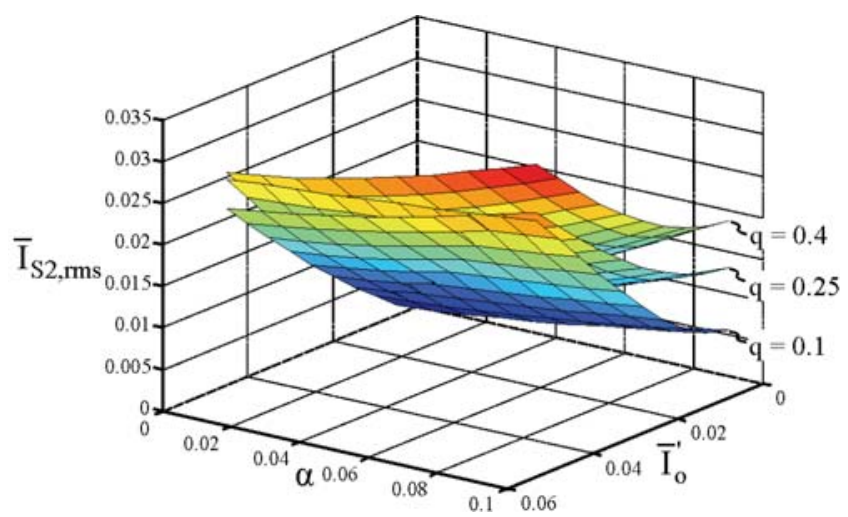

Fig. 7. Normalized RMS value of switch $S_{2}$ current. 


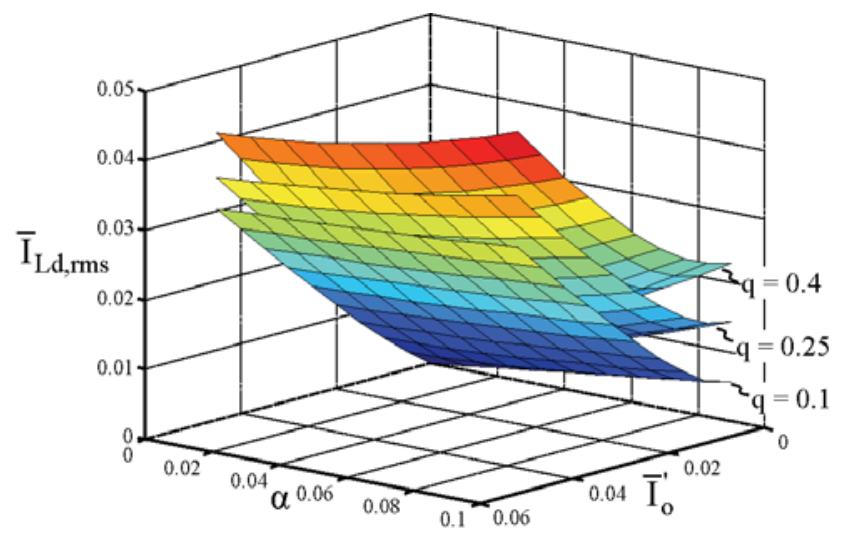

Fig. 8. Normalized RMS value of inductor $L_{d}$ current.

As expected, an increase in the value of parameter $\alpha$ leads to a higher current stress in the inductor $\mathrm{L}_{\mathrm{d}}$, thus contributing to increase the conduction losses in this component.

Finally, the current stresses on diodes $\mathrm{D}_{3}$ and $\mathrm{D}_{4}$ are computed, and results are shown in Figures 9 and 10.

These results demonstrate that RMS value of the diode $\mathrm{D}_{3}$ current is slightly increased as $\alpha$ value becomes higher. Regarding diode $\mathrm{D}_{4}$ current, its RMS value decreases as $\alpha$ increases. This behavior is due to duty cycle adjustment in order to maintain the same transfer characteristic as $\alpha$ value changes, which acts toward reducing the time interval where $\mathrm{D}_{4}$ remains forward biased within one switching cycle. Therefore, diode $\mathrm{D}_{4}$ is the only ASHB converter component which conduction losses are reduced when lowering the magnetizing inductance value.

\section{EXPERIMENTAL RESULTS}

In order to verify the results obtained from the analyses carried out in the previous sections a $500 \mathrm{~W}$ ASHB converter prototype was built. A picture of the prototype is presented in Figure 11 and main design specifications are given in Table I. The power stage components list is shown in Table II.

The commutation inductor $\mathrm{L}_{\mathrm{d}}$ was constructed using a Thornton NEE-30/7 ferrite core with a 10-turn winding. An IC UC3525 is employed to generate the PWM signals

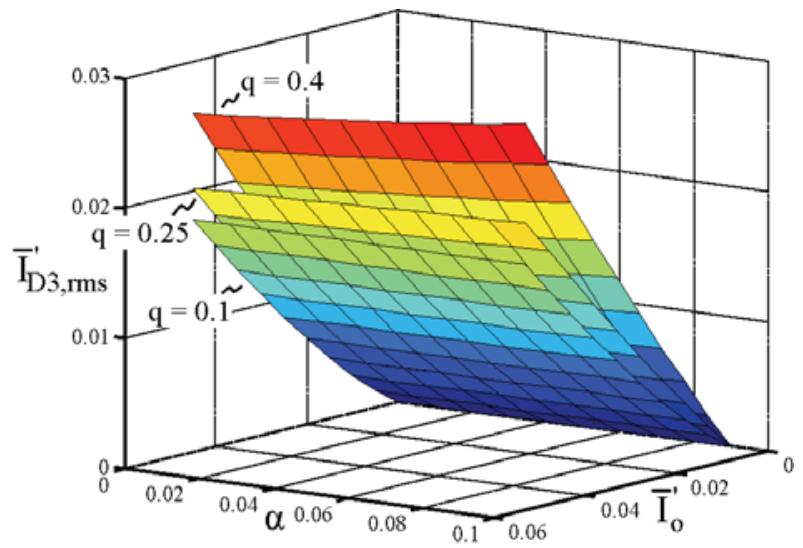

Fig. 9. Normalized RMS value of diode $\mathrm{D}_{3}$ current.

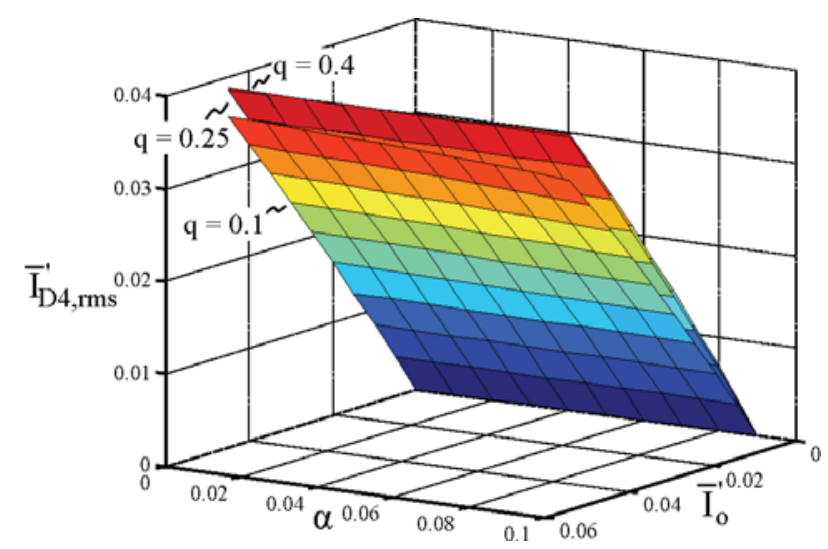

Fig. 10. Normalized RMS value of diode $\mathrm{D}_{4}$ current.

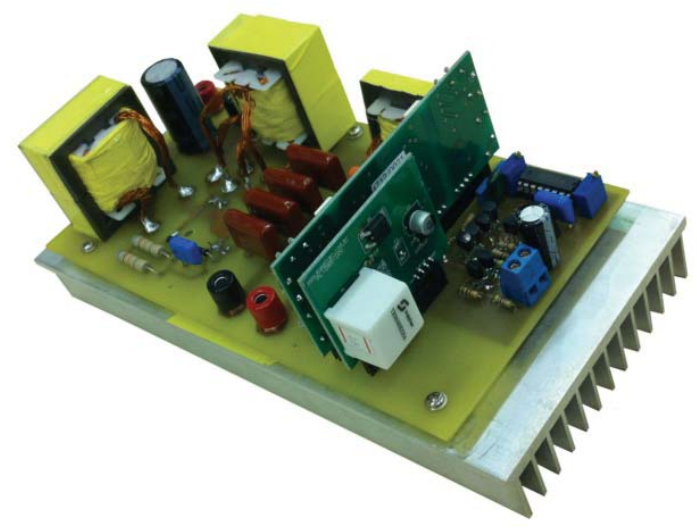

Fig. 11. Picture of the $500 \mathrm{~W}$ ASHB converter prototype.

A Thornton NEE-42/20 ferrite core with 28 turns was used in the inductor $\mathrm{L}_{0}$ construction. The same Thornton NEE-42/20, with 21 turns in the primary side and $11+11$ turns in the secondary side was used to build the high frequency transformer. Since the leakage inductance is not an issue in this converter (it appears in series with $\mathrm{L}_{\mathrm{d}}$ ), no advanced technique, such as interleaving primary and secondary windings, was employed for its construction. The magnetizing inductance value was set by adjusting the transformer's core gap length.

In order to validate the theoretical analysis, the RMS current values of the ASHB components are shown in Table III. Table III provides the experimental, simulation and theoretical results of current stresses for the operating conditions of $50 \mathrm{~W}$ and $500 \mathrm{~W}$. The discrepancies observed on the RMS values of diodes $\mathrm{D}_{3}$ and $\mathrm{D}_{4}$ currents are due to the fact that the duty cycle had to be increased during the experimental tests in order to compensate the converter losses. The same occurs for currents on switches $S_{1}$ and $S_{2}$, although it is minimized since their peak values also change toward maintaining their average value equal (direct result from the converter analysis). Regarding inductor $\mathrm{L}_{\mathrm{d}}$, which current RMS value dependency on duty cycle is not high, the results converge, thus bringing credibility to the analysis carried out.

Next are presented the experimental waveforms of gateto-source and drain-to-source voltages for both switches $S_{1}$ and $S_{2}$ during the commutation for several operating conditions. 
TABLE I

Converter Design Specifications

\begin{tabular}{cc}
\hline Specification & Value \\
\hline Output power $\left(\mathrm{P}_{\mathrm{o}}\right)$ & $500 \mathrm{~W}$ \\
\hline Input voltage $\left(\mathrm{V}_{\text {in }}\right)$ & $300 \mathrm{~V}$ \\
\hline Output voltage $\left(\mathrm{V}_{\mathrm{o}}\right)$ & $60 \mathrm{~V}$ \\
\hline Switching frequency $\left(\mathrm{f}_{\mathrm{s}}\right)$ & $50 \mathrm{kHz}$ \\
\hline Maximum output current ripple $\left(\Delta \mathrm{I}_{\mathrm{Lo}}\right)$ & $10 \%$ of $\mathrm{I}_{\mathrm{o}}$ \\
\hline Maximum output voltage ripple $\left(\Delta \mathrm{V}_{\mathrm{o}}\right)$ & $1 \%$ of $\mathrm{V}_{\mathrm{o}}$ \\
\hline
\end{tabular}

TABLE II

Power Stage Components List

\begin{tabular}{cc}
\hline Name & Component \\
\hline Switches $\mathrm{S}_{1}$ and $\mathrm{S}_{2}$ & IRF740 (MOSFET) \\
\hline Diodes $\mathrm{D}_{3}$ and $\mathrm{D}_{4}$ & MUR860 \\
\hline $\mathrm{L}_{\mathrm{d}}$ & $15 \mu \mathrm{H}$ \\
\hline $\mathrm{L}_{\mathrm{o}}$ & $340 \mu \mathrm{H}$ \\
\hline $\mathrm{C}_{\mathrm{o}}$ & $100 \mu \mathrm{F}$ \\
\hline $\mathrm{C}_{1}$ and $\mathrm{C}_{2}$ & $2.8 \mathrm{nF}$ \\
\hline Turns ratio $\left(\mathrm{n}=\mathrm{N}_{\mathrm{p}} / \mathrm{N}_{\mathrm{s}}\right)$ & 2 \\
\hline
\end{tabular}

TABLE III

Theoretical, Simulated and Experimental RMS Current Values of ASHB Components

\begin{tabular}{|c|c|c|c|c|c|}
\hline & \multirow{2}{*}{$\begin{array}{c}\mathbf{L}_{\mathrm{m}} \\
\mathbf{P}_{\mathbf{o}}\end{array}$} & \multicolumn{2}{|c|}{$250 \mu \mathbf{H}$} & \multicolumn{2}{|c|}{$1000 \mu \mathbf{H}$} \\
\hline & & $50 \mathrm{~W}$ & $500 \mathrm{~W}$ & $50 \mathrm{~W}$ & $500 \mathrm{~W}$ \\
\hline \multirow{3}{*}{$\begin{array}{c}\mathrm{I}_{\mathrm{S} 1, \mathrm{rms}} \\
{[\mathrm{A}]}\end{array}$} & Theoretical & 1.18 & 2.91 & 0.36 & 2.49 \\
\hline & Simulated & 1.13 & 2.95 & 0.31 & 2.51 \\
\hline & Experimental & 1.18 & 2.90 & 0.36 & 2.67 \\
\hline \multirow{3}{*}{$\begin{array}{c}\mathrm{I}_{\mathrm{S} 2, \mathrm{rms}} \\
{[\mathrm{A}]}\end{array}$} & Theoretical & 0.85 & 3.08 & 0.37 & 2.98 \\
\hline & Simulated & 0.90 & 3.14 & 0.39 & 3.00 \\
\hline & Experimental & 1.00 & 2.92 & 0.42 & 2.70 \\
\hline \multirow{3}{*}{$\begin{array}{c}\mathrm{I}_{\mathrm{Ld}, \mathrm{rms}} \\
{[\mathrm{A}]}\end{array}$} & Theoretical & 1.46 & 4.24 & 0.52 & 3.89 \\
\hline & Simulated & 1.45 & 4.31 & 0.51 & 3.91 \\
\hline & Experimental & 1.61 & 4.18 & 0.50 & 3.92 \\
\hline \multirow{3}{*}{$\begin{array}{c}\mathrm{I}_{\mathrm{D} 3, \mathrm{rms}} \\
{[\mathrm{A}]}\end{array}$} & Theoretical & 0.47 & 5.21 & 0.45 & 4.94 \\
\hline & Simulated & 0.49 & 5.27 & 0.47 & 4.98 \\
\hline & Experimental & 0.66 & 5.86 & 0.55 & 5.92 \\
\hline \multirow{3}{*}{$\begin{array}{c}\mathrm{I}_{\mathrm{D} 4, \mathrm{rms}} \\
{[\mathrm{A}]}\end{array}$} & Theoretical & 0.69 & 6.32 & 0.70 & 6.52 \\
\hline & Simulated & 0.70 & 6.35 & 0.71 & 6.52 \\
\hline & Experimental & 0.53 & 5.83 & 0.62 & 5.96 \\
\hline
\end{tabular}

Figure 12 shows $\mathrm{v}_{\mathrm{S} 1}$ and $\mathrm{v}_{\mathrm{gS} 1}$ for $\mathrm{L}_{\mathrm{m}}=1 \mathrm{mH}$ and $\mathrm{P}_{\mathrm{o}}=500$ $\mathrm{W}(100 \%$ of rated power) while Figure 13 presents the results for $\mathrm{S}_{2}$ considering the same conditions. These results demonstrate that ZVS turn-on is achieved for both $S_{1}$ and $S_{2}$, which is expected since the converter operates under full load conditions.

The same waveforms are presented in Figures 14 and 15 for $S_{1}$ and $S_{2}$, respectively, considering the case where the output power is decreased to $50 \mathrm{~W}$ (10\% of rated power) while maintaining the magnetizing inductance equal to $1 \mathrm{mH}$ $\left(\alpha=1.478 \times 10^{-2}\right)$. Here, it is evident that ZVS turn-on was lost for both switches due to the operation at light load conditions and small $\alpha$ value.

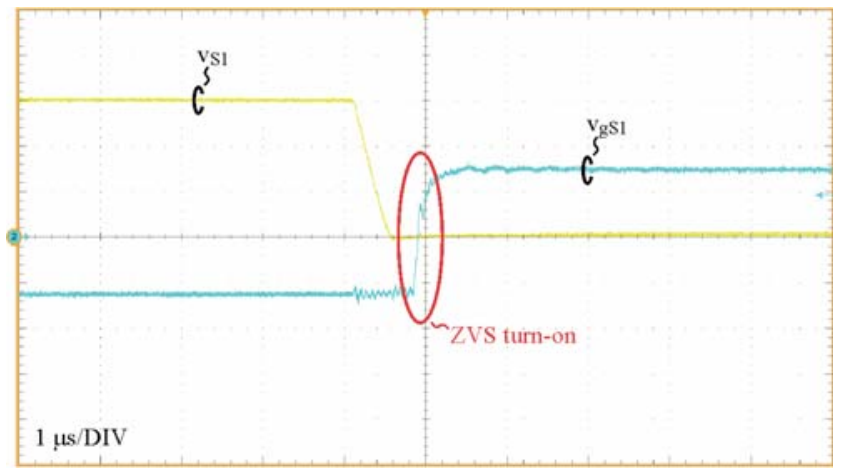

Fig. 12. Voltages $\mathrm{V}_{\mathrm{S} 1}(100 \mathrm{~V} /$ div $)$ and $\mathrm{V}_{\mathrm{gS} 1}(10 \mathrm{~V} /$ div $)$ waveforms for $\mathrm{L}_{\mathrm{m}}=1 \mathrm{mH}$ and $\mathrm{P}_{\mathrm{o}}=500 \mathrm{~W}$.

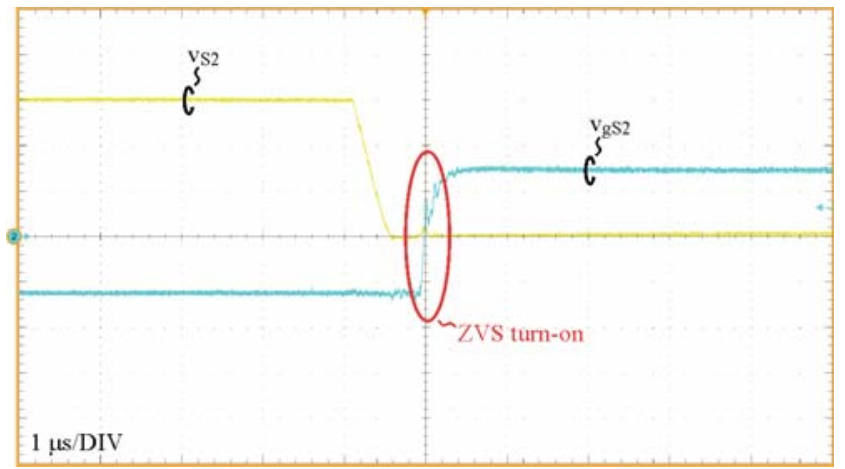

Fig. 13. Voltages $\mathrm{V}_{\mathrm{S} 2}(100 \mathrm{~V} /$ div $)$ and $\mathrm{V}_{\mathrm{gS} 2}(10 \mathrm{~V} /$ div $)$ waveforms for $\mathrm{L}_{\mathrm{m}}=1 \mathrm{mH}$ and $\mathrm{P}_{\mathrm{o}}=500 \mathrm{~W}$.

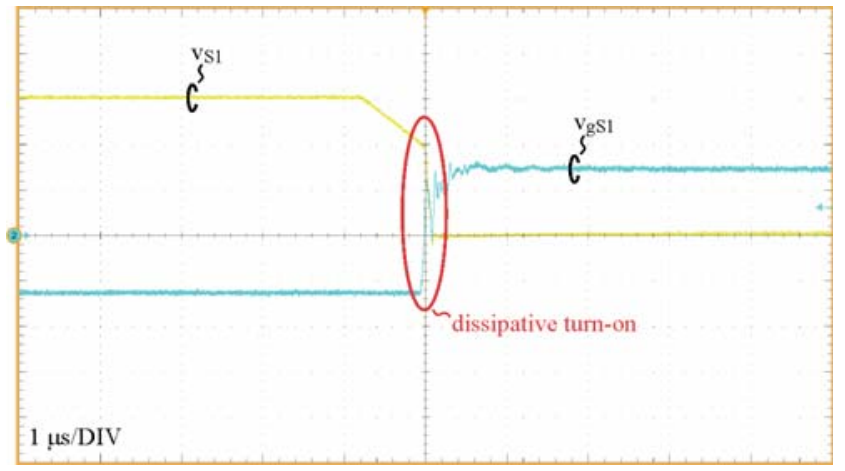

Fig. 14. Voltages $\mathrm{V}_{\mathrm{S} 1}(100 \mathrm{~V} /$ div $)$ and $\mathrm{V}_{\mathrm{gS} 1}(10 \mathrm{~V} /$ div $)$ waveforms for $\mathrm{L}_{\mathrm{m}}=1 \mathrm{mH}$ and $\mathrm{P}_{\mathrm{o}}=50 \mathrm{~W}$.

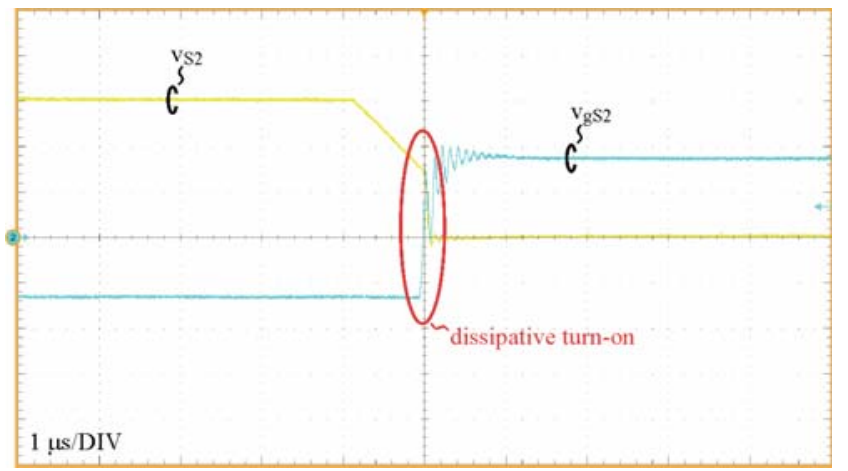

Fig. 15. Voltages $\mathrm{V}_{\mathrm{S} 2}(100 \mathrm{~V} /$ div $)$ and $\mathrm{V}_{\mathrm{gS} 2}(9 \mathrm{~V} /$ div $)$ waveforms for $\mathrm{L}_{\mathrm{m}}=1 \mathrm{mH}$ and $\mathrm{P}_{\mathrm{o}}=50 \mathrm{~W}$. 
Now, the next results are given considering that $\alpha$ was increased to $5.66 \times 10^{-2}\left(\mathrm{~L}_{\mathrm{m}}=250 \mu \mathrm{H}\right)$. At full load condition $\left(\mathrm{P}_{\mathrm{o}}=500 \mathrm{~W}\right)$, commutation of $\mathrm{S}_{1}$ and $\mathrm{S}_{2}$ are shown in Figures 16 and 17, respectively. As expected, ZVS turn-on is still achieved for both switches, even though $\mathrm{L}_{\mathrm{m}}$ value was changed, once the converter operates with $100 \%$ of rated power.

Finally, Figures 18 and 19 present the commutation of the ASHB converter switches when maintaining $\alpha$ equal to 5.66 $\mathrm{x} 10^{-2}\left(\mathrm{~L}_{\mathrm{m}}=250 \mu \mathrm{H}\right)$ and decreasing $\mathrm{P}_{\mathrm{o}}$ to $50 \mathrm{~W}(10 \%$ of rated power). It becomes evident from these results the improvement on the switching conditions of both switches. ZVS turn-on is achieved for $S_{2}$ even under light load conditions. Regarding $\mathrm{S}_{1}$, the commutation is dissipative but presents lower losses if compared to the case of $\mathrm{L}_{\mathrm{m}}=1 \mathrm{mH}$ (Figure 14), since the switch voltage at the moment of $S_{1}$ turn-on is lower in this case.

The efficiency of the ASHB converter is presented in Figure 20, considering four distinct cases of magnetizing inductance values: $\mathrm{L}_{\mathrm{m}}=1 \mathrm{mH}, \mathrm{L}_{\mathrm{m}}=750 \mu \mathrm{H}, \mathrm{L}_{\mathrm{m}}=500 \mu \mathrm{H}$ and $\mathrm{L}_{\mathrm{m}}=250 \mu \mathrm{H}$. It is important to observe that these values result in: $\alpha=1.478 \times 10^{-2}, \alpha=1.961 \times 10^{-2}, \alpha=2.913 \times 10^{-2}$ and $\alpha=5.66 \times 10^{-2}$, respectively.

In order to observe the details of the converter efficiency operating at full load conditions, Figure 21 shows an expanded view of the graph presented in Figure 20. This result shows an efficiency degradation as $\mathrm{L}_{\mathrm{m}}$ is decreased (equivalent to $\alpha$ increase) due to higher current stresses on the ASHB power stage components.

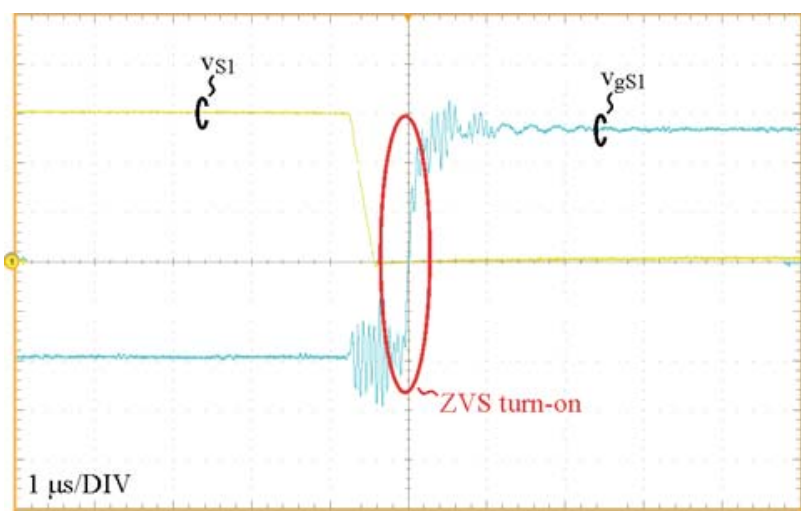

Fig. 16. Voltages $\mathrm{V}_{\mathrm{S} 1}(100 \mathrm{~V} /$ div $)$ and $\mathrm{V}_{\mathrm{gS} 1}(6 \mathrm{~V} /$ div $)$ waveforms for $\mathrm{L}_{\mathrm{m}}=250 \mu \mathrm{H}$ and $\mathrm{P}_{\mathrm{o}}=500 \mathrm{~W}$.

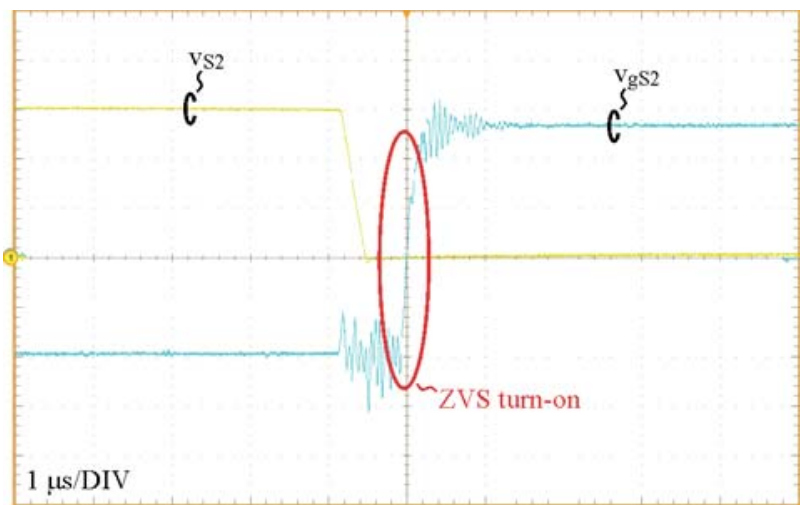

Fig. 17. Voltages $\mathrm{V}_{\mathrm{S} 2}(100 \mathrm{~V} /$ div $)$ and $\mathrm{V}_{\mathrm{gS} 2}(6 \mathrm{~V} /$ div $)$ waveforms for $\mathrm{L}_{\mathrm{m}}=250 \mu \mathrm{H}$ and $\mathrm{P}_{\mathrm{o}}=500 \mathrm{~W}$.

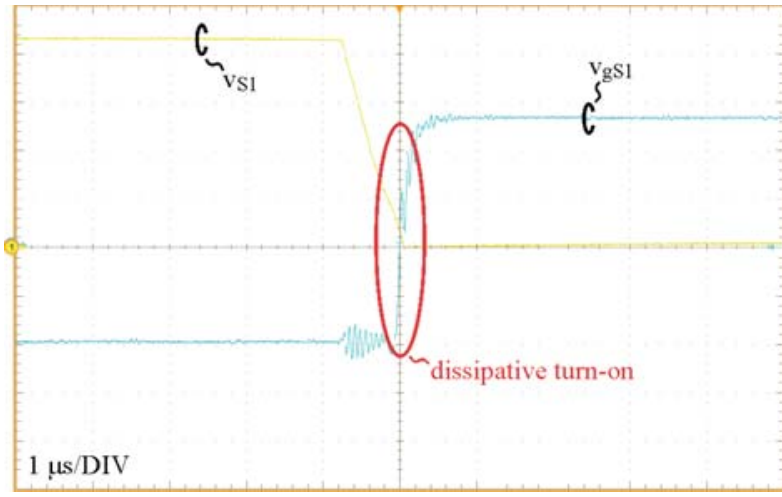

Fig. 18. Voltages $\mathrm{V}_{\mathrm{S} 1}(70 \mathrm{~V} /$ div $)$ and $\mathrm{V}_{\mathrm{gS} 1}(6 \mathrm{~V} /$ div $)$ waveforms for $\mathrm{L}_{\mathrm{m}}=250 \mu \mathrm{H}$ and $\mathrm{P}_{\mathrm{o}}=50 \mathrm{~W}$.

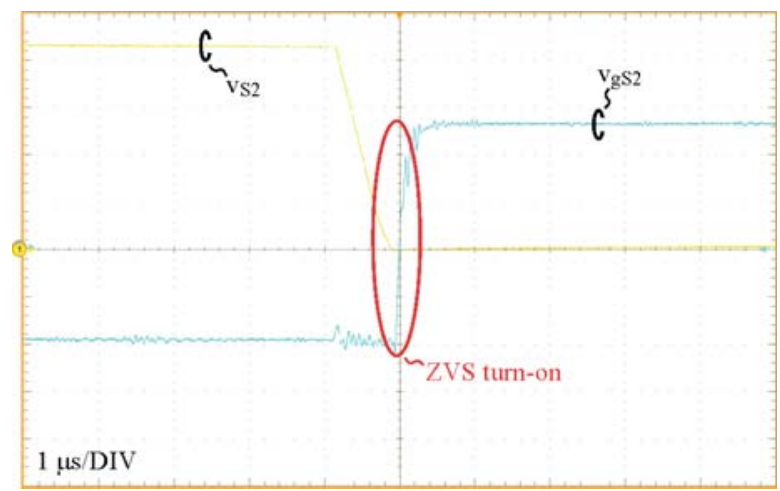

Fig. 19. Voltages $\mathrm{V}_{\mathrm{S} 2}(70 \mathrm{~V} /$ div $)$ and $\mathrm{V}_{\mathrm{gS} 2}(6 \mathrm{~V} /$ div $)$ waveforms for $\mathrm{L}_{\mathrm{m}}=250 \mu \mathrm{H}$ and $\mathrm{P}_{\mathrm{o}}=50 \mathrm{~W}$.

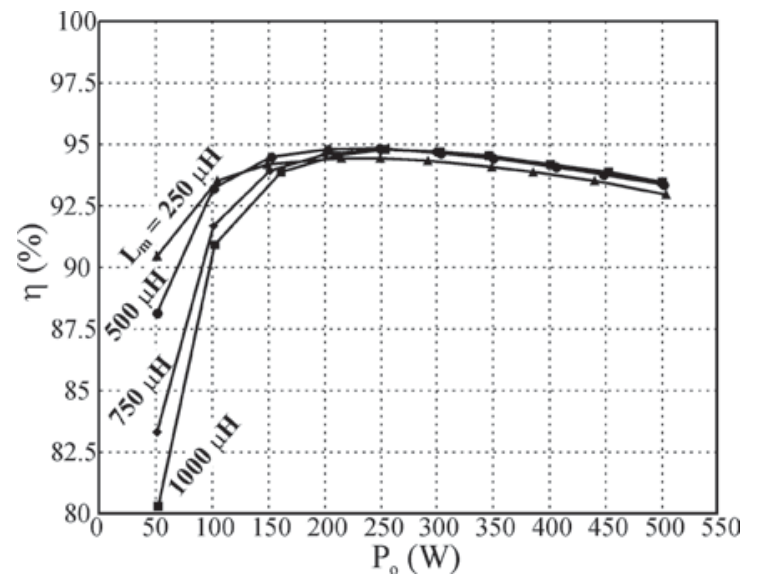

Fig. 20. Measured ASHB converter efficiency for several values of magnetizing inductance.

\section{CONCLUSION}

The quantitative analysis of the magnetizing inductance value influence on current stresses of the asymmetrical halfbridge converter was carried out in this paper. It was observed that most of RMS currents of the ASHB converter elements are increased as $\mathrm{L}_{\mathrm{m}}$ value is decreased, which leads to higher conductions losses. The exception is diode $\mathrm{D}_{4}$, which RMS current decreases as $\mathrm{L}_{\mathrm{m}}$ value is decreased. It was also evident the improvement of switching conditions under light load conditions for lower values of magnetizing inductance, which allows a converter design for wide-ZVSrange operation. 


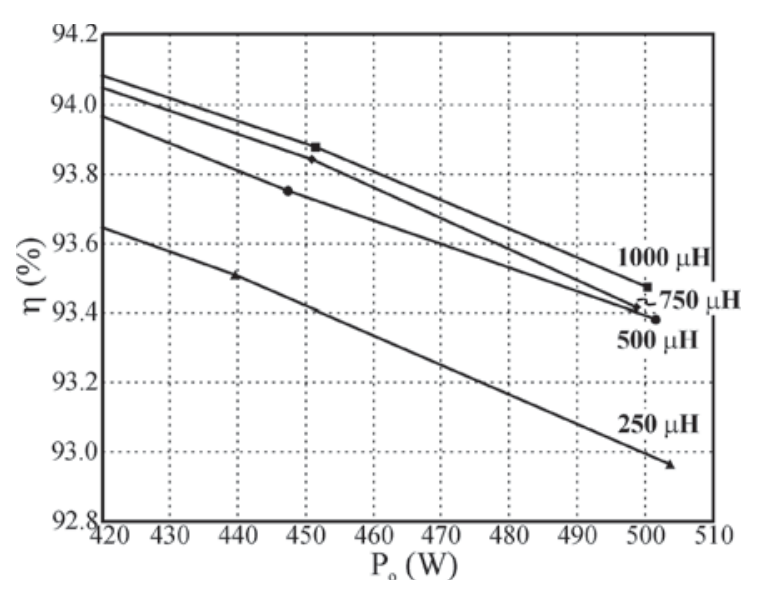

Fig. 21. Expanded view of ASHB converter efficiency at heavy load conditions.

A $500 \mathrm{~W}$ ASHB converter prototype was built to perform the experimental analysis. For the case where the magnetizing inductance was set to $250 \mu \mathrm{H}$, the converter efficiency was higher than $90 \%$ within the entire range of $10 \%$ to $100 \%$ of output load. However, there was an efficiency penalty at medium and heavy load conditions due to higher conductions losses caused by the lowered value of magnetizing inductance.

Although this proposal reduces the efficiency at rated power the wide ZVS range is achieved without the addition of extra components, which implies in cost reduction.

\section{REFERENCES}

[1] M. Pahlevaninezhad, P. Das, J. Drobnik, P. K. Jain, A. Bakhshai, "A Novel ZVZCS Full-Bridge DC/DC Converter used for Electric Vehicles", IEEE Transactions on Power Electronics, vol. 27, no. 6, pp. 2752-2769, June 2012.

[2] D. Christen, S. Tschannen, J. Biela, "Highly Efficient and Compact DC-DC Converter for Ultra-Fast Charging of Electric Vehicles", in Proc. of EPE-PEMC - 15th International Power Electronics and Motion Control Conference, pp. LS5d.3-1-LS5d.3-8, 2012.

[3] B. Gu, C.-Y. Lin, B. F. Chen, J. Dominic, J.-S. Lai, "Zero-Voltage-Switching PWM Resonant Full-Bridge Converter with Minimized Circulating Losses and Minimal Voltage Stresses of Bridge Rectifiers for Electric Vehicle Battery Chargers", IEEE Transactions on Power Electronics, vol. 28, no. 10, pp. 4657-4667, October 2013.

[4] U. R. Prasanna, A. K. Rathore, "Extended Range ZVS Active-Clamped Current-Fed Full-Bridge Isolated DC/DC Converter for Fuel Cell Applications: Analysis, Design, and Experimental Results”, IEEE Transactions on Industrial Electronics, vol. 60, no. 7, pp. 2661-2672, July 2013.

[5] Y.-D. Kim, K.-M. Cho, D.-Y. Kim, B.-H. Lee, C.-H. Kim, G.-W. Moon, "Wide Range ZVS Phase Shift Full Bridge Converter with Low Conduction Loss", in Proc. of ICPE \& ECCE - IEEE 8th International Conference on Power Electronics and ECCE Asia, pp. 340-346, 2011.
[6] Y.-D. Kim, K.-M. Cho, D.-Y. Kim, G.-W. Moon, "Wide-Range ZVS Phase-Shift Full-Bridge Converter with Reduced Conduction Loss Caused by Circulating Current", IEEE Transactions on Power Electronics, vol. 28, no. 7, pp. 3308-3316, July 2013.

[7] W. Chen, X. Ruan, J. Ge, "A Novel Full-Bridge Converter Achieving ZVS over Wide Load Range with a Passive Auxiliary Circuit", in Proc. of ECCE - Energy Conversion Congress and Exposition, pp. 1110-1115, 2013.

[8] P. Xuewei, P. R. Prasanna, A. K. Rathore, "MagnetizingInductance-Assisted Extended Range Soft-Switching Three-Phase AC-Link Current-Fed DC/DC Converter for Low DC Voltage Applications", IEEE Transactions on Power Electronics, vol. 28, no. 7, pp. 3317-3328, July 2013.

[9] M. Narimani, G. Moschopoulos, "A New DC/DC Converter with Wide-Range ZVS and Reduced Circulating Current", in Proc. of ECCE - Energy Conversion Congress and Exposition, pp. 2209-2214, 2011.

[10]M. Narimani, G. Moschopoulos, “A New DC/DC Converter with Wide-Range ZVS and Reduced Circulating Current", IEEE Transactions on Power Electronics, vol. 28, no. 3, pp. 1265-1273, March 2013.

[11]Z. Ye, "Dual Half-Bridge DC-DC Converter with WideRange ZVS and Zero Circulating Current", IEEE Transactions on Power Electronics, vol. 28, no. 7, pp. 3276-3286, July 2013.

[12]I.-O. Lee, G.-W. Moon, "Phase-Shifted PWM Converter with a Wide ZVS Range and Reduced Circulating Current", IEEE Transactions on Power Electronics, vol. 28, no. 2, pp. 908-919, February 2013.

[13]O. G. da Rocha, C. H. Illa Font, E. Agostini Junior, "Magnetizing-Current-Assisted Wide ZVS Range Isolated DC-DC Converters", in Proc. of COBEP Brazilian Power Electronics Conference, pp. 236-242, 2013.

[14]J. L. Duarte, J. Lokos, F. B. M. van Horck, "Phase-ShiftControlled Three-Level Converter with Reduced Voltage Stress Featuring ZVS over the Full Operation Range", IEEE Transactions on Power Electronics, vol. 28, no. 5, pp. 2140-2150, May 2013.

[15]Y. Shi, X. Yang, “Zero-Voltage Switching PWM ThreeLevel Full-Bridge DC-DC Converter with Wide ZVS Load Range", IEEE Transactions on Power Electronics, vol. 28, no. 10, pp. 4511-4524, October 2013.

[16]T. Ninomiya, N. Matsumoto, M. Nakahara, K. Harada, "Static and Dynamic Analysis of Zero-Voltage-Switched Half-Bridge Converter with PWM Control", In Proc. of PESC - 22 $2^{\text {nd }}$ Annual IEEE Power Electronics Specialists Conference, pp. 230-237, 1991.

\section{BIOGRAPHIES}

Carlos Henrique Illa Font was born in Erval Grande, Rio Grande do Sul, Brazil, in 1976. He received the B.Sc., M.Sc. and Ph.D. degrees in electrical engineering from Federal University of Santa Catarina, Brazil, in 2001, 2003 and 2009, respectively. 
Since 2010 he is with Federal University of TechnologyParaná, Câmpus Ponta Grossa, Brazil. His interest areas include PFC converters, three-phase AC-DC converters and switching-mode power supplies for industrial applications.

Prof. Carlos is Member of IEEE Power Electronics Society, IEEE Industrial Electronics Society and Brazilian Power Electronics Society (SOBRAEP).
Eloi Agostini Junior was born in Lages, SC, Brazil, on January 19, 1983. He received the B.S., M.S. and Ph.D. degrees from the Federal University of Santa Catarina in 2006, 2008 and 2012, respectively. $\mathrm{He}$ is currently a Professor in the Electronics Department of the Federal University of Technology - Paraná. His interest research areas include dc-dc converters, soft-switching, converter modeling and renewable energy processing. 